\title{
IL3RA Gene
}

National Cancer Institute

\section{Source}

National Cancer Institute. IL3RA Gene. NCI Thesaurus. Code C39274.

This gene is involved in signal transduction and several diverse biological processes. 